\title{
Origin of the gabbro-anorthosite-related Fe-Ti-V deposit at Otanmäki (central Finland): historical perspectives and topics of future research
}

\author{
K. Kärenlampi ${ }^{1 *}$, A. Mäkisalo ${ }^{1}$, A. Kontinen ${ }^{2}$ and J. Jylänki ${ }^{3}$ \\ ${ }^{1}$ Oulu Mining School, P.O. Box 3000, 90014 University of Oulu, Finland \\ ${ }^{2}$ Geological Survey of Finland, P.O. Box 1237, 70211 Kuopio, Finland \\ ${ }^{3}$ Otanmäki Mine Oy Kiilakiventie 1, 90250 Oulu, Finland \\ *Corresponding author e-mail: kimmo.karenlampi@oulu.fi
}

\begin{abstract}
Summary The Otanmäki area in central Finland encompasses a gabbro-hosted Fe-Ti-V oxide deposit, which was mined between 1953-1985. The oxide ore occurs as semi-massive to massive magnetiteilmenite lenses and discontinuous layers in a heterogenous zone consisting of gabbro and magnetite gabbro with fragments of anorthosite. Previous studies have proposed a magmatic origin for the Fe-Ti$\mathrm{V}$ mineralization but details of the specific igneous processes, which resulted in the oxide ore bodies, remain poorly understood.
\end{abstract}

\section{Introduction}

The Otanmäki area in central Finland has been the subject of geological research since the discovery of gabbro-hosted magmatic Fe-Ti-V oxide deposits in the area in the 1930s (Paarma, 1954; Pääkkönen 1956; Kerkkonen, 1979; Lindholm and Anttonen, 1980; Nykänen, 1995; Huhma et al., 2018; Mäkisalo, 2019). The largest of the oxide deposits, the Otanmäki deposit, was an important global producer of vanadium during its operation between 1953-1985. In total, $30 \mathrm{Mt}$ of magnetite-ilmenite ore was mined, grading $32-34 \% \mathrm{Fe}, 5.5-7.6 \% \mathrm{Ti}$, and $0.26 \%$ V. According to the Otanmäki Mine Oy company's interim mineral resource estimate (Hokka and Lepistö, 2019), the remaining resources at Otanmäki are classified to the inferred category and estimated to be about $24 \mathrm{Mt} @ 28 \% \mathrm{Fe}, 10 \% \mathrm{Ti}, 0.21 \% \mathrm{~V}$.

Despite the long history of geological investigation, considerable uncertainty on many aspects of the geology and origin of the Otanmäki Fe-Ti-V oxide mineralization still prevail. In previous studies, the origin of the oxide ore has been related to primary magmatic crystallization plus textural modification during regional metamorphism. The metamorphic overprinting was important economically as recrystallization of magmatic ilmenomagnetite (magnetite with micro-intergrowths of ilmenite) produced separate grains of ilmenite and magnetite, which allowed their effective separation in the beneficiation of the ore (Kerkkonen, 1979). However, the specific igneous differentiation processes, which led to the extreme Fe-Ti-V enrichment in the Otanmäki magma chamber, have remained poorly understood.

In this study, based on our recently obtained field, petrographical and whole-rock major and trace element and available previous data, we propose a revised model of the internal structure of the Otanmäki intrusion and discuss the processes which resulted in the Fe-Ti-V mineralization.

\section{Geology of the Otanmäki intrusion}

The ca. 2.06 Ga Otanmäki mafic intrusion is hosted in Archean TTG-series (tonalitetrondhjemite-granodiorite) gneisses (Fig. 1). The intrusive body was foliated and metamorphosed under amphibolite facies conditions during the Svecofennian orogeny (1.9-1.8 $\mathrm{Ga})$. It is divided into three major blocks, which have mostly fault contacts against the 
surrounding Archean TTG gneisses and ca. 2.05 Ga A-type granites and intermediate igneous rocks (Fig. 1). Each block bears laterally continuous oxide ore zones, which are remarkably voluminous in relation to the small size of the whole gabbroic body (Fig. 1).

Based on our field and petrographic observations, the Otanmäki intrusion can be divided into three major units, the Lower Zone, the Ore Zone, and the Upper Zone (Figs. 1 and 2). The rocks in the Lower Zone have relatively well-preserved magmatic mineral compositions and textures, but in the Ore Zone and Upper Zone, the rocks are foliated and show metamorphic mineral assemblages.

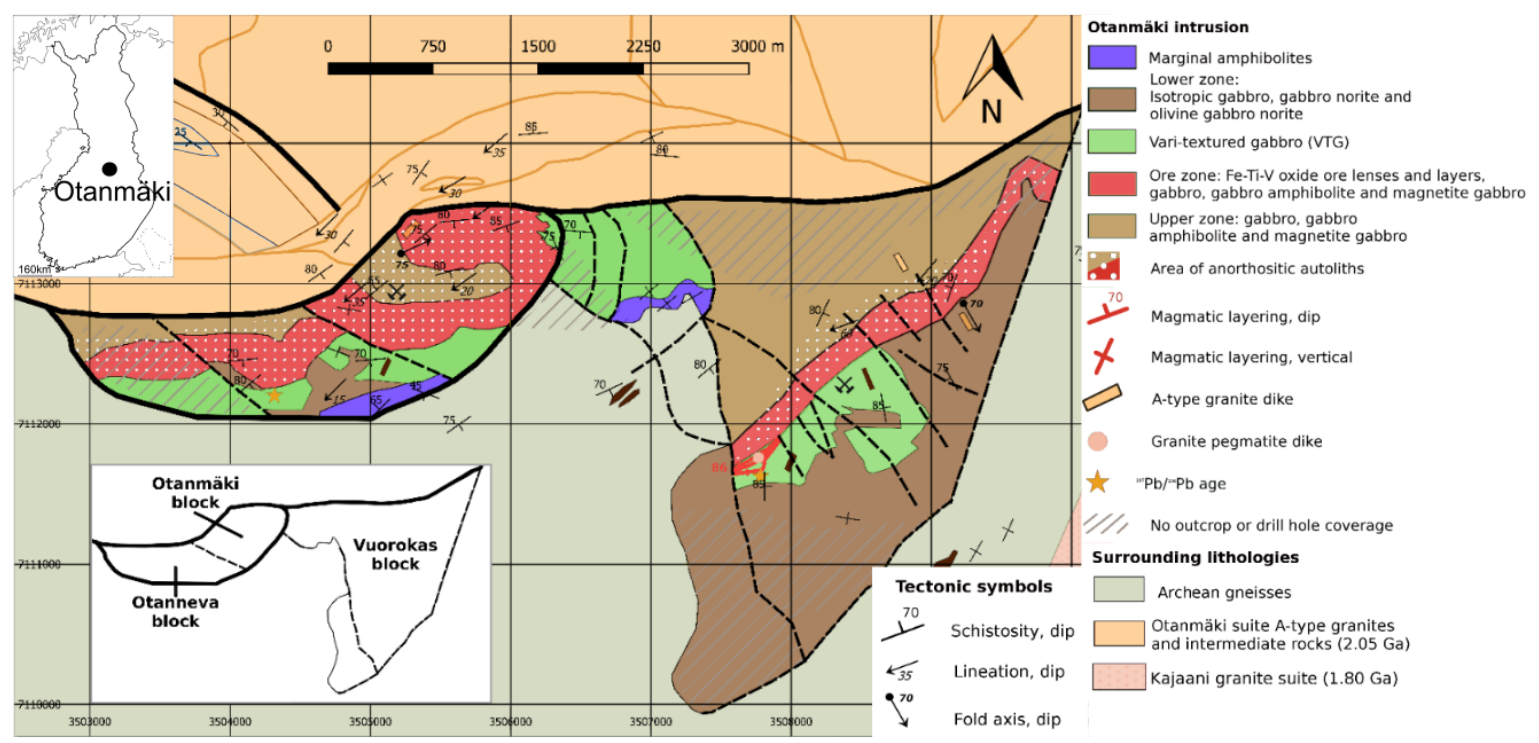

Figure 1. Geological map of the Otanmäki intrusion (Mäkisalo, 2019).

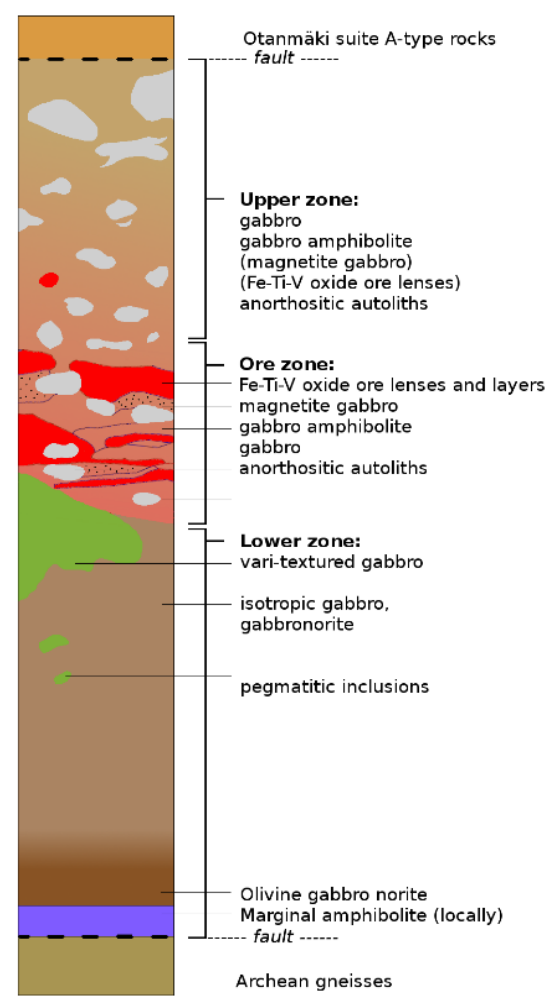

Figure 2. Schematic magmatic stratigraphy of the Otanmäki intrusion (not to scale) (Mäkisalo, 2019). 
The Lower Zone consists mostly of medium- to coarse-grained isotropic gabbro and gabbronorite, which are associated with variably-sized and irregularly shaped bodies (1- to 500$\mathrm{m}$ in diameter) of pegmatoidal varitextured gabbro (VTG) (Figs. 1 and 2). The VTGs show a large variation in the grain size $(2$ to $50 \mathrm{~cm}$ ) and color index on an outcrop scale, ranging in composition from gabbronorite to anorthosite. They have both gradational and irregular contacts to isotropic gabbro-gabbronorites.

The Lower Zone rocks show a sharp transition to the Ore Zone, which comprises semimassive to massive oxide ore lenses and layers, gabbro, magnetite gabbro and gabbro amphibolite. The oxide ore is distributed in numerous semi-massive to massive magnetiteilmenite lenses, or, more rarely, discontinuous layers, which are 3-50 m wide and up to $200 \mathrm{~m}$ long (Fig. 3). The Ore Zone rock assemblage changes gradually into the Upper Zone, where isotropic gabbro dominates and oxide ore is no longer present. Both the Ore and Upper Zone gabbros portray occasional modal layering, but it is not a prevailing feature. In addition, countless, angular to subrounded anorthositic autoliths of 1-30 meters in diameter are met throughout the Ore and Upper Zones (Figs. 1-3). An interesting feature is that some of the autoliths are fully enclosed within oxide ore, suggesting that the solidification of the highdensity oxide ore postdated the emplacement of some of the anorthositic autoliths.

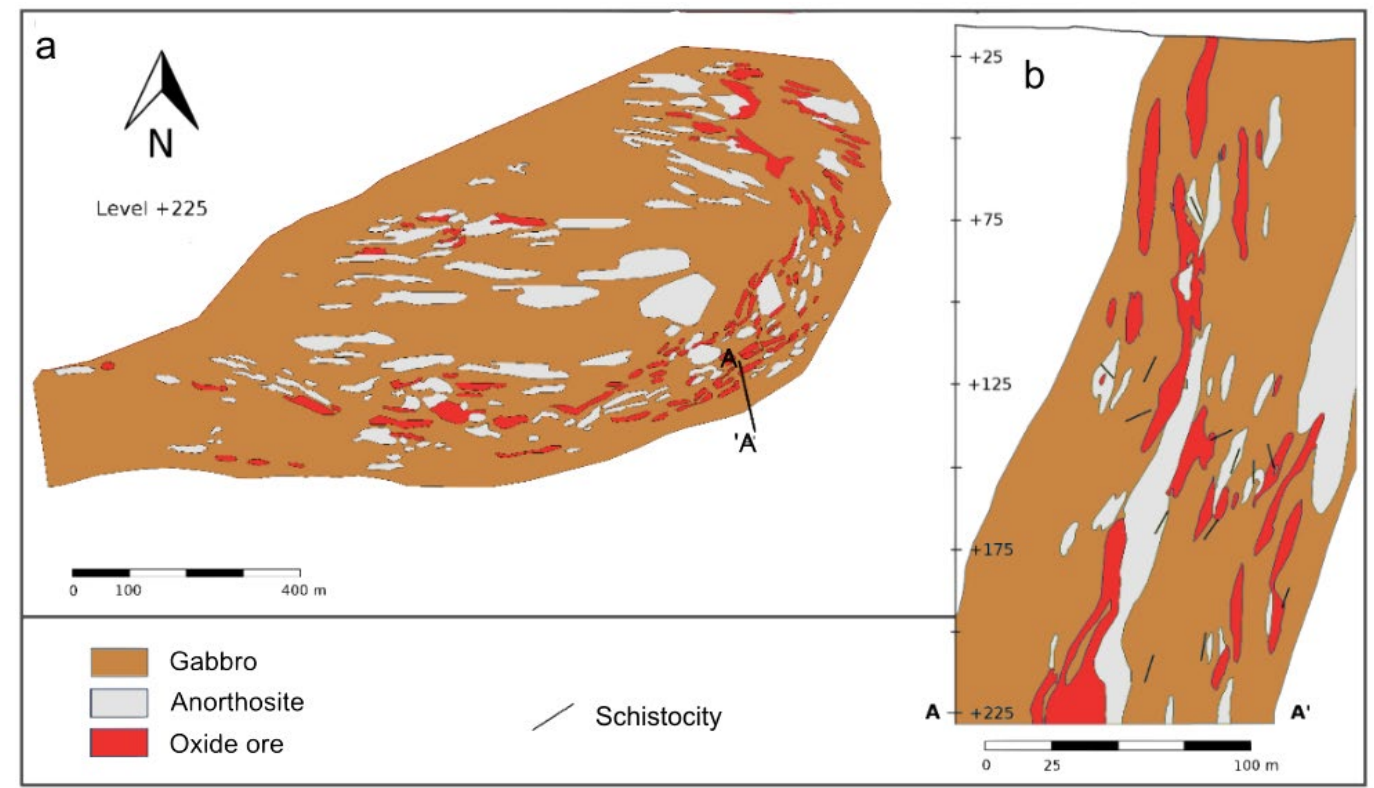

Figure 3. a) Geological map of the +225 level of the Otanmäki Ore Zone. b) Cross section of the ore zone at A-A' in a. Modified after Lindholm and Anttonen (1980).

\section{Previous models of oxide ore genesis and topics of future research}

The first investigators, Paarma (1954) and Pääkkönen (1956), recognized that the wall rocks of the oxide ore are metamorphosed gabbroic rocks and ore resembles many other titaniferous iron ores of magmatic origin known at the time. According to Paarma (1954), the ore was formed by direct crystallization from a Fe-Ti-rich magma. However, the generally strongly deformed nature of the ore bodies and their wall rocks made Pääkkönen (1956) to propose that the accumulation of oxide minerals and formation of the ore bodies were related to metamorphic segregation of primary (magmatic) disseminated oxide minerals from the gabbroic wall rocks.

Kerkkonen (1979) and Nykänen (1995) proposed that crystallization of pyroxenes, plagioclase and olivine from a Fe-Ti-rich tholeiitic parental magma under highly reducing and relatively high-pressure conditions ( $\sim 7 \mathrm{kbar}$ ) resulted in Fe-Ti-V enrichment in the residual melt 
and abundant crystallization of oxide minerals in the Otanmäki magma chamber. Kerkkonen (1979) described that the rocks of the least deformed parts of the Ore Zone display magmatic cumulus textures, flow lamination and turbulence structures around anorthosite autoliths. $\mathrm{He}$ suggested that two mechanisms were important in the Otanmäki magma chamber: 1) flotation and accumulation of plagioclase in the roof part of the magma chamber, particularly in the early stages of magmatic evolution, and 2) magmatic flow that enhanced density-driven differentiation resulting in high-density floor cumulates, and caused brecciation, entrapment and transport of the earlier formed plagioclase-rich roof cumulates to deposit as autoliths on the floor of the magma chamber. Based on the complex spatial association of the irregular-shaped oxide ore bodies with anorthositic autoliths and gabbroic wall rocks, Kerkkonen (1979) also suggested that turbulent magmatic flow on earlier formed basal cumulates, and around autoliths deposited on them, may have locally produced small-scale physicochemical heterogeneities in the magma, which promoted selective in-situ crystallization of magnetite only.

The previous views on the origin of Otanmäki Fe-Ti-V deposit are largely conceptual and lacking strong supporting evidence, and many basic issues of the magmatic evolution of the Otanmäki magma chamber have not yet been addressed. For example, it remains to be answered whether the magma chamber evolved in open- or closed-system conditions. In this respect, it would be highly interesting to model how much Fe-tholeiitic parental magma is required to produce the mass of each component in the Otanmäki intrusion, including the Fe$\mathrm{Ti}-\mathrm{V}$ oxide ores. Compared to typical oxide ores in layered intrusions, one distinct feature of the Ore Zone in Otanmäki is the distribution of ore in numerous discontinuous, lens-like oxiderich bodies (Fig. 2). How this situation arouse is a big research question. It also remains unresolved how the pegmatoidal VTG bodies just beneath the Ore Zone rocks were formed and whether their origin was linked to the Fe-Ti-V mineralization processes. Detailed petrological modelling on the crystallization processes, especially the changing of magma density during magma evolution, would be critical to decipher these issues. In addition, modeling would require additional detailed geological and geochemical mapping to accurately demonstrate the map to outcrop-scale distribution of different components within the intrusion.

\section{References}

Hokka J, Lepistö S (2019) Technical report for Otanmäki V-Ti-Fe project, Finland.

Huhma H, Hanski E, Kontinen A, Vuollo J, Mänttäri I, Lahaye Y (2018) Sm-Nd and U-Pb isotope geochemistry of the Paleoproterozoic mafic magmatism in eastern and northern Finland. Geological Survey of Finland, Bulletin 405, $150 \mathrm{p}$.

Kerkkonen O (1979) Genesis and evolution of the Otanmäki titanium-iron ore in the light of the magnetite-ilmenite pair. Licentiate Thesis, University of Oulu, Finland. (in Finnish)

Lindholm O, Anttonen R (1980) Geology of the Otanmäki Mine. In: Häkli TA (ed) Precambrian Ores of Finland. Guide to Excursions 078 A + C, Part 2 (Finland). Proceedings of the 26th International Geological Congress. Geological Survey of Finland, Espoo, pp. 25-33.

Mäkisalo A (2019) Geological characterization of anorthositic rocks in the Otanmäki intrusion, central Finland: constraints on magma evolution and Fe-Ti-V oxide ore genesis. MSc Thesis, University of Oulu, $128 \mathrm{p}$.

Nykänen V (1995) Crystallization and chemical evolution of the lower-and central part of the Vuorokas block in the Otanmäki intrusion complex. Licentiate Thesis, University of Oulu, 135 p. (in Finnish)

Pääkkönen V (1956) Otanmäki the ilmenite-magnetite ore field in Finland. Bull. Comm. géol. Finlande 171, 71 p.

Paarma H (1954) The ilmenite-magnetite ore deposit of Otanmäki. In: Aurola E (ed) The mines and quarries of Finland. Geologinen tutkimuslaitos -geoteknillisiä julkaisuja 55, 36-42. Geological Survey of Finland. 